\title{
Criminal Law Policy Against Non-Bank Foreign Exchange Business Activities (KUPVA-BB) or Illegal Money Changer in Indonesia
}

\author{
Binsan Ripmal Simangkir ${ }^{1} \quad$ Sihabudin $^{2} \quad$ Iwan Permadi $^{2} \quad$ Herman Suryokumoro $^{2}$ \\ 1. Ph.D Candidate at Faculty of Law, Brawijaya University, Indonesia \\ 2. Lecturer at Faculty of Law, Brawijaya University, Indonesia
}

\begin{abstract}
The Practice of Non-Bank Foreign Exchange Business Activities (KUPVA-BB) or illegal Money Changer cannot be touched by law by using Bank Indonesia Regulation Number 18/20 / PBI / 2016, dated October 7, 2016, about KUPVA-BB. Illegal KUPVA-BB practices or practices cannot be put in order through law enforcement mechanisms, because the current regulations as legality for conducting law enforcement cannot reach. They are free to do their business in Indonesia to obtain the greatest profit, without taking care of their business licenses, the perpetrators do not pay taxes to the state from the results of their efforts. The purpose of this research is to find out how criminal law policy towards KUPVA-BB in Indonesia. This research is a legal research with a law approach, comparative approach, and conceptual approach. The analysis technique in this research was carried out in a literature study and documentary study. The results showed that the business activities of exchanging non-bank foreign currencies or illegal money changers required the existence of a rule that contains legal norms that can be used as legality in law enforcement. Non-bank currency exchange business activities are illegal or money changers, such as prohibitions against illegal practices, the law against illegal practices, the authority of law enforcement and the law regulating KUPVA-BB.
\end{abstract}

Keywords: Non-Bank Foreign Exchange Business Activities (KUPVA-BB), illegal money changers, law enforcement, legality.

DOI: $10.7176 / \mathrm{JLPG} / 90-05$

Publication date:October $31^{\text {st }} 2019$

\section{Introduction}

Indonesia's improving economic growth and supported by controlled national security stability has increased the interest of international investors to invest in Indonesia. The arrival of investors to invest is investing in Indonesia, coupled with the interest of foreign tourists visiting Indonesia to increase the need for services to foreigners in Indonesia. The arrival of the person, with various interests, urgently needs the availability of a currency exchange facility or money changer.

In Indonesia, Money Changer was initially only in a bank environment. In its framework, Money Changer is integrated with the operations of the bank itself. Until now, Money Changer in the bank is still operating. The development of the economy and the community's need for exchange of foreign currency into cash and the need for the exchange of rupiah into foreign currency or foreign currencies has increased, the government through Bank Indonesia has made a policy to form a financial institution outside the bank in the form of Exchange Business Activities Non-Bank Foreign Currency abbreviated as KUPVA-BB or as we know it as Money Changer. The existence of Money Changer is currently in two institutions, namely bank institutions, and nonbank institutions.

The existence of KUPVA-BB or Money Changer is currently more in locations or places that are frequently visited by tourists, in Indonesia. The KUPVA-BB or Money Changer money exchange institution is one of the needs to provide services and facilitate transaction activities. The mechanism carried out in trading or exchanging Valsas with Money Changer is by "Selling and Buying Foreign Banknotes (UKA), and also purchasing traveler's checks". ${ }^{1}$ The process of exchanging Forex must submit the original Foreign Banknotes (UKA) physically, while for the exchange of money in the form of Rupiah, it can be done either physically, or by transferring via intra-bank or inter-bank.

Regulations concerning Non-Bank Currency Exchange Business Activities (KUPVA-BB) or Money Changer are not regulated in the form of laws, and in regulations of Bank Financial Institutions and Non-Bank Financial Institutions, KUPVA-BB activities are also not found.

That the regulation of KUPVA-BB or Money Changer is only regulated in the Indonesian Bank Regulation (PBI), namely Number 18/20 / PBI / 2016 concerning Non-Bank Foreign Exchange Business Activities (KUPVA-BB). Bank Indonesia regulation as mentioned above, regulates the implementation, licensing, prohibition and sanctions for KUPVA-BB actors who have officially obtained permission from Bank Indonesia.

\footnotetext{
${ }^{1}$ Anni Muslimah Purnamawati, Konsep Qiyas Dalam Transaksi Ekonomi Money Changer, Ekomadania Volume 1. Nomor 1. Juli 2017.
} 
Based on legal material from Bank Indonesia, in 2017 there were 1,064 (one thousand sixty-four) units of unauthorized Money Changer or did not have a license from Bank Indonesia. Of that number, 404 of them are in Jakarta, Bogor, Depok, Tangerang, and Bekasi. While others are spread throughout Indonesia. ${ }^{1}$ Bank Indonesia assesses that there are three illegal KUPVA-BB or Money Changer business models, which consist of, an individual company, a travel bureau that doubles as a money changer, a gold shop and a money changer, an electronics store that doubles money changers, a shop or stall concurrently a money changer, and a kiosk that specifically doing Money Changer activities. Sales or exchange of money by companies is done by receiving cash or by transfer, while shops or kiosks usually do this by exchanging foreign banknotes in cash.

The Governor of Bank Indonesia, explained that Money Changer is not licensed or illegal, has the potential to be used for criminal acts of money laundering, corruption, and drug transactions, to finance activities against terrorism. "Even so many smuggling goods into Indonesia, the financing is allegedly through KUPVA-BB or Money Changer is not licensed or illegal.

Basically, the existence of KUPVA-BB in Indonesia is very beneficial for the nation and state and society in general. There is a value obtained from the practice of KUPVA-BB, namely profits from business results that can increase revenue, which brings positive benefits, but different from KUPVA-BB or illegal Money Changer practice, which performs its actions as a means of criminal acts and other acts that are can harm the country and society.

Efforts to curb have been carried out by Bank Indonesia together with the National Police-Criminal Investigation Unit as law enforcement officers, but these activities have no positive impact to reduce the number of illegal Money Changer, because after the enforcement is carried out a few days later the illegal Money Changer businessman deliberately reopens his business without regard to Bank Regulations Indonesia, so it seems that the curbing is only for a moment and does not change the behavior of KUPVA-BB or illegal Money Changer entrepreneurs to comply with Bank Indonesia Regulation No. 18/20 / PBI / 2016 to take care of their business licenses to become legal. Why does this happen, due to the absence of rules or regulations that contain legal norms that contain legal sanctions, to force illegal KUPVA-BB or Money Changer businesses to comply with the rules as stipulated in Bank Indonesia Regulation Number 18/20 / PBI / 2016 concerning Activities NonBank Currency Exchange Business. Based on legal material obtained from the Directorate of Economic Crimes and the Criminal Investigation Agency and the National Police, it shows that the organizers of illegal money changers were disciplined in the 2017 and 2018 periods.

Table 1. List of Illegal Money Changer Controls 2017-2018

\begin{tabular}{|c|c|c|c|}
\hline No & Date & Region & Amount of Money Changer ordered \\
\hline 11 & 10-Apr-17 & Medan & 2 \\
\hline 22 & 10-Apr-17 & Jakarta, Bogor dan Depok & 5 \\
\hline 23 & 10-Apr-17 & Bali & 22 \\
\hline 24 & 11-Apr-17 & Medan & 3 \\
\hline 25 & 11-Apr-17 & Jakarta, Bogor dan Depok & 8 \\
\hline 26 & 11-Apr-17 & Bali & 20 \\
\hline 27 & 12-Apr-17 & Medan & 3 \\
\hline 28 & 12-Apr-17 & Jakarta, Bogor dan Depok & 11 \\
\hline 29 & 12-Apr-17 & Bali & 5 \\
\hline 210 & 25-Apr-17 & DIY & 18 \\
\hline 111 & 26-27 April 2017 & Solo & 9 \\
\hline 112 & 10-11 Agst 2017 & Tangerang & 10 \\
\hline \multicolumn{3}{|c|}{ Sub Total for 2017} & 116 \\
\hline 113 & 1-3 Agustus 2018 & Karawang & 10 \\
\hline 114 & 23-Agu & Jakarta Selatan & 2 \\
\hline \multicolumn{3}{|c|}{ Sub Total for 2018} & 10 \\
\hline \multicolumn{3}{|c|}{ Total } & 128 \\
\hline
\end{tabular}

Source: Directorate of Economic Crimes and the National Police-Criminal Investigation Agency

Whereas from a number of KUPVA-BB or Illegal Money Changer ordered by Bank Indonesia together with the Criminal Investigation Police, none of the law enforcement efforts were carried out to impose sanctions, due to Bank Indonesia Regulation Number 18/20 / PBI / 2016, which is used as a legal basis in controlling, there is no norm that imposes legal sanctions to ensnare and force the perpetrators of illegal KUPVA-BB or Money Changer to obey the rules.

They are free to make efforts in Indonesia to obtain the greatest profit, without taking care of their business licenses, the perpetrators do not pay taxes to the state from the results of their efforts. The business people enjoy

\footnotetext{
${ }^{1}$ https://katadata.co.id/berita/2017/06/05/bi-gandeng-polri-tertibkan-783-money-changer-ilegalu, accessed on October $13,2018$.
} 
the facilities and infrastructure in the form of public facilities provided by the state. But the illegal KUPVA-BB actors deliberately did not take care of their business licenses and they could not be touched by the law.

Unlike the KUPVA-BB which has an official permit from Bank Indonesia. Bank Indonesia Regulation Number 18/20/2016, does not provide legal norms governing illegal KUPVA-BB or KUPVA-BB that do not have official permission from Bank Indonesia, even though they are free to carry out their business activities. Bank Indonesia regulations only regulate KUPVA-BB which are official or those that have official permits.

With regard to legal issues that occur as a result of the practice of illegal Non-Bank Foreign Exchange Business Activities (KUPVA-BB), there are problems that need to be resolved. The state must not be silent, the state must be present if legal problems occur like this in the community. Based on the description in the background above, in this study, the formulation of the problem to be discussed is about How the criminal law policy towards Non-Bank Foreign Exchange Business Activities (KUPVA-BB) going forward.

\section{Methodology}

This type of research is normative juridical research which is a process to find the rule of law, legal principles and legal doctrines in order to address the legal issues encountered. ${ }^{1}$ The research approach used is the statutory approach, comparative approach, and conceptual approach. Sources of legal materials used are primary legal materials (rules and regulations, writings or official records, or also treatises, which are found in making regulations and legislation including decisions of judges in court), secondary (legal books, legal journals, legal magazines, legal articles, and obtained from the internet in the form of legal readings and legal cases) and tertiary (legal material that can provide instructions or explanations to strengthen primary and secondary legal materials, such as those originating from from legal encyclopedias and dictionaries). The analysis technique in this research was carried out in a literature study and documentary study. ${ }^{2}$

\section{Results and Discussion}

Law enforcement against the perpetrators of the practice of Non-Bank Currency Exchange Business Activities (KUPVA-BB) or illegal Money Changer, it is necessary to have a law as a legal umbrella or legality that is the norm governing about acts that are violated, and norms that regulate legal sanctions for the perpetrators of KUPVA-BB who violate the law, it is necessary to do a legal policy in the form of issuance of laws.

\section{Prohibition of illegal KUPVA-BB practices}

Judging from the Political Theory of law, that to form a regulation or legislation it is necessary to have the will of the people, through representation in the House of Representatives, to make or issue a law. So if it is related to the existence of Non-Bank Foreign Exchange Business Activities (KUPVA-BB) that practice illegally, which is regulated in Bank Indonesia Regulation Number 18/20 / PBI / 2016 dated October 7, the regulation does not formulate a norm regulates the prohibition of illegal KUPVA-BB practices. So the legality to control and enforce the law against KUPVA-BB illegal does not have legal norms. Therefore, it is necessary to formulate norms that contain restrictions on future KUPVA-BB practices.

These norms must be able to limit illegal KUPVA-BB actors in carrying out their activities, and if the KUPBA-BB actors carry out activities without being equipped with official permission from the government, then the norm will become a legal umbrella for law enforcers who are able to provide legal sanctions, so as such will reduce the perpetrators of illegal KUPBA-BB, and in the end can provide benefits to the state and criminal acts by using illegal KUPVA-BB facilities can be minimized.

In 2011 Mahrus Ali reiterated that Political Law is an effort to realize good regulations according to circumstances and situations at a time. So if the process of law enforcement against Illegal Exchange (KUPVABB) Illegal Currency Exchange Business Activities will be disciplined, it requires regulation or legislation as an umbrella in law enforcement. Where the law is the will of all the people of Indonesia that is implemented through people's representatives in the House of Representatives whose authority is to form a law.

With the law made by the will of all Indonesian people, normatively legal norms are regulating the prohibition of illegal KUPVA-BB practices, and there is a necessity that must be carried out by the perpetrators of Foreign Exchange Business Activities in Indonesia. And the law also contains formulations on granting authority to the state through law enforcement officials, to carry out law enforcement for the perpetrators of Foreign Exchange Business Activities which require actions in Indonesia.

\section{Legal Sanctions Against Illegal KUPVA-BB Practice}

Judging from the theory of legal policy, the purpose of criminal law policy, which is also familiar with the Theory of Criminalization, which is to uphold the rule of law, protect the legal community. Humans are one by one in a society interdependent where their interests and relations between them are determined and protected by norms. But when it comes to more important matters, sanctions (law), through the order of state law that

\footnotetext{
${ }^{1}$ Marzuki, Peter Mahmud. Penelitian Hukum (Jakarta : Kencana Prenada Media, 2011), p.35

${ }^{2}$ Abdlatif and Hasbi Ali. Perihal Kaedah Hukum, (Bandung : Citra Aditya Bakti, 2010), p.9.
} 
complements social structuring, are refined, strengthened and imposed on violators of these norms. ${ }^{1}$ Two central problems in criminal policy using the means of punishment (criminal law is a matter of determination, what actions should be used as a criminal offense and what sanctions should be used or imposed on the offender. In essence, the criminalization policy is part of a criminal policy using criminal law facilities, and therefore included as part of criminal law policies. ${ }^{2}$

In order to tackle crime, various facilities are needed as a reaction that can be given to perpetrators of crime, in the form of criminal or non-criminal sanctions, which can be integrated with one another. Moreover, criminal means are considered relevant to tackling crime, meaning that a political conception of criminal law is needed..$^{3}$ Two points of thought in the criminalization policy by using the means of punishment (criminal law), namely the determination of the problems: ${ }^{4}$

a. What should be a crime, ${ }^{5}$ and;

b. What sanctions should be imposed on the offender.

In addition to paying attention to these criteria, it also needs to consider the existence of significant losses or casualties, both actual and potential from the act. Because, remembering victims of corporate crime often do not feel that they have become victims, and that is different from conventional crime victims. Moreover, efforts to fight for the interests of victims have required a long journey. In this regard, J.E. Sahetapy states that:

The paradigmology paradigm is not only related to crime in the classical sense, but also concerns other acts outside the realm of criminal law. Abuse o power, clearly indicates, that the act of abusing power means that it can also be carried out by a legitimate power. That means that having power does not automatically mean having the truth. So, the people can be sacrificed for the sake of the ruling or the ruling group without paying attention or heeding or respecting legal and or moral norms. ${ }^{6}$

In line with the theory of legal policy, as mentioned above, it is necessary to have legal certainty that contains legal norms. The legal norms can be formed in writing or not in writing by the institutions authorized to form them. The norms contain prohibitions and imperatives and will impact legal sanctions for those who violate them.

If you listen to the above legal norms, it is very clear that Bank Indonesia Regulation Number: 18 / PBI / 20/2016 concerning Non-Bank Foreign Exchange Business Activities (KUPVA-BB) does not regulate a legal principle related to the regulation or prohibition of KUPVA-BB practice is illegal in Indonesia, so that legal sanctions against illegal actors cannot be applied.

Therefore, the principle that requires that the criminal justice system in criminal law enforcement should be based on the proportional between the interests of society, the interests of the state, and the interests of perpetrators of crime and the interests of victims. With this principle, the criminal justice system is not just carrying out and implementing the law, but to what extent the application of the law is reasonable and meets the desired goals. Based on the description, it is necessary to have a criminal law policy against the perpetrators of the business activities of exchanging foreign exchange (KUPVA-BB) or illegal money changers that make criminal legal norms concerning legal arrangements that contain prohibitions and legal sanctions against illegal KUPVA-BB actors in Indonesia. The mechanism that can be carried out is by law enforcement that provides sanctions that have the effect of preventing the occurrence of illegal KUPVA-BB practices, and if the illegal KUPVA-BB actors do not comply with the provisions of applicable laws and regulations, the law contains with clear strict legal sanctions against the perpetrators in the form of criminal sanctions both criminal sanctions in the form of confinement or imprisonment and criminal sanctions in the form of fines in accordance with the proportional amount of money so that it does not even add to the burden both on society and on the state as the sovereign holder to carry out criminal law enforcement. Thus order and prosperity will be achieved in the community as desired by the law itself.

\section{Authority of law enforcement against illegal KUPVA-BB practices}

Reviewed with the theory of legal certainty, that law enforcement can be done if there is legal certainty, and legal certainty can be done, if there are provisions or provisions. Related to the business activities of illegal NonBank Currency Exchange (KUPVA-BB), a definite legal rule is needed that can be used as a legal basis for carrying out law enforcement efforts against illegal KUPVA-BB actors. Legal certainty is a question that can only be answered normatively, not sociology.

Business Activities of Non-Bank Foreign Exchange (KUPVA-BB) or Money Changer that conducts

\footnotetext{
1 Jan Remmelink, Hukum Pidana (Komentar atas Pasal-Pasal Terpenting dari Kitab Undang-Undang Hukum Pidana Belanda dan Padanannya dalam Kitab Undang-Undang Hukum Pidana Indonesia), Op.Cit, p. 14.

${ }^{2}$ Barda Nawawie Arief, Bunga Rampai Kebijakan Hukum Pidana. (Bandung : PT Citra Aditya Bakti, 2008). p. 2-3.

${ }^{3}$ Ali, Mahrus. Dasar-dasar Hukum Pidana. (Jakarta: Sinar Grafika, 2011), p. 109.

${ }^{4}$ Barda Nawawi Arief. Kebijakan Legislatif Dalam Penanggulangan Kejahatan Dengan Pidana Penjara. (Semarang: Undip,2000), p. 35.

${ }^{5}$ Abdul Hamid, Teori Negara Hukum Modern, (Bandung: CV.Pustaka Setia, 2016), p. 44-48

${ }^{6}$ J.E. Sahetapy. Bunga Rampai Viktimisasi. (Bandung : Eresco, 1995), p. V.
} 
business activities throughout the territory of the Republic of Indonesia must be controlled and supervised by the state through the Institution which is authorized to supervise. Bank Indonesia as a state institution as the central bank must be given authority to oversee the activities of KUPVA activities in Indonesia. And if in the course of the KUPVA-BB is found violating the law, then the legal norms containing prohibitions and sanctions as the norms formulated in the law, will become the law to carry out law enforcement, which is also as a suggestion for control, reducing the occurrence of criminal acts committed by means of KUPVA-BB.

The legal means is a method, to change the illegal Non-Bank Foreign Exchange (KUPVA-BB) Business Activity to become legal. This effort is carried out by carrying out law enforcement to crack down on these illegal perpetrators, so they want to take care of business licenses into a legal business activity, by becoming a legal entity that was previously illegal, it is hoped they will become taxpayers who pay income tax to the state as state capital to build service facilities and infrastructure for the community.

With the existence of legal norms that contain prohibitions and legal sanctions, a concrete law is found to fill the legal vacuum in the framework of regulating Non-Bank Foreign Exchange Business Activities (KUPVA$\mathrm{BB})$ in the future, as a legal update to the existing regulation as regulated in Bank Indonesia Regulation Number : 18 / PBI / 20/2016 concerning Non-Bank Foreign Exchange Business Activities, or better known as Money Changer, is not contained in several regulations or laws.

Bank Indonesia Regulation Number: 18 / PBI / 20/2016, there is no formulation of legal norms regulating the prohibition of illegal KUPVA-BB practices and does not regulate norms that contain legal sanctions that are forcing against business actors who carry out illegal practices. Attributive legal regulations give authority or rights to legal subjects ${ }^{1}$. For example, legal regulations that give authority to the formation of laws, authority to adjudicate and executive authority and civil law regulations relating to property rights. The government as the ruler, in this case law enforcement as a body that is given the task and responsibility to enforce the law, cannot perform its function and authority to carry out law enforcement against illegal KUPVA-BB workers, because in Bank Indonesia regulation Number: 18 / PBI / 20/2016 does not contain legal norms containing sanctions against illegal KUPVA-BB actors.

\section{Criminal Law Policy Against illegal KUPVA-BB practices in the future}

Non-Bank Foreign Currency Exchange Business Activities or illegal money changers as stipulated in Bank Indonesia Regulation Number: 18 / PBI / 20/2016 concerning Non-Bank Foreign Exchange Business Activities and the laws above which are considered for issuance of Bank Indonesia regulations do not regulate prohibition, sanction, authority to the state apparatus to enforce and supervise the Non-Bank Currency Exchange Business Activities or illegal money changers recommended, for:

1. Making the formulation of legal norms containing prohibitions, sanctions, authority to state officials to carry out enforcement and oversight of Non-Bank Foreign Exchange Business Activities or illegal money changers;

2. As the formulation of the norms above, can be formulated into legislation by increasing Bank Indonesia Regulation Number: 18 / PBI / 20/2016 concerning Non-Bank Foreign Exchange Business Activities into law; and

3. Formulation of norms regarding prohibitions, sanctions, authority to state apparatus to carry out enforcement and supervision of Non-Bank Foreign Currency Exchange Business Activities or illegal money changers can be added in the form of additional articles into existing laws namely Law Number 7 of 2011 concerning Currency Money, where the law is the law most relevant to NonBank Foreign Exchange Business Activities.

\section{Conclusions}

Non-Bank Foreign Currency Exchange Business Activities or illegal money changers have caused implications so that to curb or carry out law enforcement against Non-Bank Foreign Currency Exchange Business Activities or illegal money changers requires a rule that contains legal norms that can be used as legality in law enforcement Non-Bank Currency Exchange Business Activities or illegal money changers, such as prohibitions on illegal practices, legal sanctions against illegal practices, law enforcement authorities and KUPVA-BB regulatory laws. Thus, the activities of the Non-Bank Foreign Exchange Business Exchange or illegal money changers can be carried out law enforcement and supervision to minimize the practice of Non-Bank Foreign Exchange Business Activities or illegal money changers and at the same time constitute a legal method to legalize Non-Bank Foreign Exchange Business Activities or illegal money changers become legal. So, if these activities become legal, they become registered companies that become taxpayers and they will contribute to the state in the form of income tax as part of state income that can be used for the construction of facilities for the welfare of the people.

\footnotetext{
${ }^{1}$ Sudikno Merto Kusumo, Perumusan hukum, (Yogyakarta: Univ. Atma Jaya, 2010), p. 14.
} 


\section{Reference}

Abdlatif and Hasbi Ali. Perihal Kaedah Hukum, (Bandung : Citra Aditya Bakti, 2010).

Abdul Hamid, Teori Negara Hukum Modern, (Bandung: CV. Pustaka Setia, 2016).

Anni Muslimah Purnamawati, Konsep Qiyas Dalam Transaksi Ekonomi Money Changer, Ekomadania Volume 1. Nomor 1. July 2017.

Ali, Mahrus. Dasar-dasar Hukum Pidana. (Jakarta: Sinar Grafika, 2011).

Barda Nawawie Arief, Bunga Rampai Kebijakan Hukum Pidana. (Bandung : PT Citra Aditya Bakti, 2008).

Barda Nawawi Arief. Kebijakan Legislatif Dalam Penanggulangan Kejahatan Dengan Pidana Penjara. (Semarang: Undip,2000).

https://katadata.co.id/berita/2017/06/05/bi-gandeng-polri-tertibkan-783-money-changer-ilegalu, accessed on October 13, 2018.

Jan Remmelink, Hukum Pidana (Komentar atas Pasal-Pasal Terpenting dari Kitab Undang-Undang Hukum Pidana Belanda dan Padanannya dalam Kitab Undang-Undang Hukum Pidana Indonesia), Op.Cit.

J.E. Sahetapy. Bunga Rampai Viktimisasi. (Bandung : Eresco, 1995).

Marzuki, Peter Mahmud.Penelitian Hukum. Edisi (Jakarta : Kencana Prenada Media, 2011).

Sudikno Merto Kusumo, Perumusan hukum, (Yogyakarta: Univ. Atma Jaya, 2010).

\section{Laws And Regulations}

Republic of Indonesia, Act Number 7 of 2011 concerning Currency (Hereinafter referred to as the Currency Act) Bank Indonesia implements an exchange rate policy based on a predetermined exchange rate system;

Republic of Indonesia, Bank Indonesia Regulation Number 18/20 / PBI / 2016 concerning Non-Bank Currency Exchange Business Activities. 